\title{
TFPI2 Gene
}

National Cancer Institute

\section{Source}

National Cancer Institute. TFPI2 Gene. NCI Thesaurus. Code C111842.

This gene plays a role in serine proteinase inhibition. 